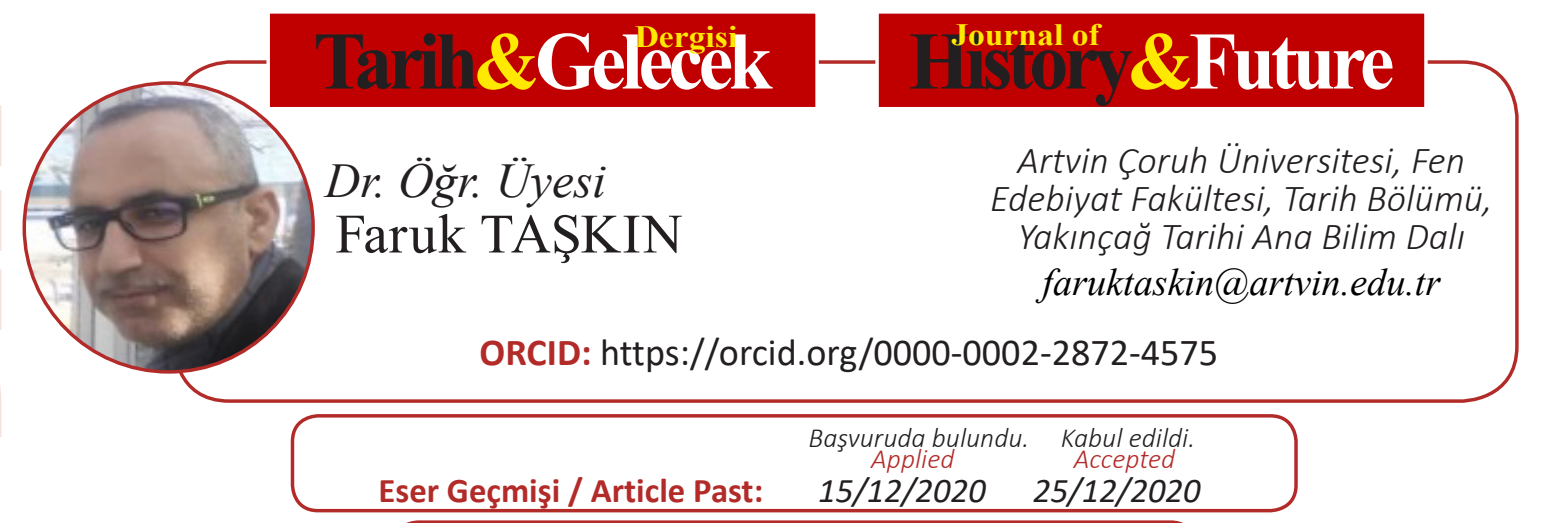

\title{
Vladimir Jabotinsky'den İngiltere Başbakanına Mektup: İngiltere Hükümetine Hizmet Etmek İstiyoruz
}

\author{
Letter from Vladimir Jabotinsky to the British Prime Minister: We Want \\ to Serve the British Government
}

\section{$\ddot{\mathbf{O} z}$}

Osmanlı Devleti’nin Birinci Dünya Savaşı’na girmesi Siyonizm’in gerçekleşmesi için politik bir ortam yaratmıştı. Bu savaş ortamında Siyonist liderler Filistin konusunda avantaj elde etmek için çeşitli girişimlerde bulundular. Siyonistler, savaş süresince İngiltere'nin desteğini almak, hatta bir Yahudi lejyon birliği ile cephede yer alarak, savaş sonrası alınacak kararlarda söz hakkı elde etmek istediler. Bu amaç için Vladimir Jabotinsky'nin fikir babası olduğu “Sion Katır Birliği” Çanakkale Savaşı'nda görev aldı. Geri hizmette görev yapan bu birliğin yeterli olmadığını düşünen Jabotinsky, İngiliz hükümetine mektup yazarak Mısır ve Filistin cephesinde aktif görev olacak bir Yahudi lejyonunun kurulması için yardım isteyecektir. Siyonistler bu eylemleriyle, Osmanlı Devleti'nin yenilgisine yardım ederken, Filistin'in kurtuluşa ermesiyle, Yahudilerin hizmetlerinin bir bütün olarak Kutsal Topraklar üzerindeki iddialarının hesaplanamayacak şekilde güçleneceğine inanıyordu. Bu çalışmada, İngiliz arşiv kayıtlarından edindiğimiz Jabotinsky'nin Yahudi lejyonunun kurulması için İngiltere hükümetine yazdığı mektuptan yola çıkarak Siyonistlerin savaşa dahil olma süreci açıklanmaya çalışılmıştır.

Anahtar Kelimeler: Yahudi Lejyonu, İngiltere, Filistin, Birinci Dünya Savaşı, Vladimir Jabotinsky.

\section{Abstract}

The entry of the Ottoman Empire into the First World War created a political environment for the realization of Zionism. In this war environment, Zionist leaders made various attempts to gain an advantage over Palestine. The Zionists wanted to get the support of Britain during the war, and they wanted to take part in the post-war decisions by even being on the front line with a Jewish legionary unit. For this purpose, the "Zion Mule Corps", of which Vladimir Jabotinsky was the mastermind, served on Gallipoli Campaign. Thinking that this corps serving in the rear service is not enough, Jabotinsky 
writes to the British government and ask for help in establishing a Jewish legion that will take active part in the Egyptian and Palestinian front. With these actions, Zionists believed that while helping to defeat Ottoman Empire, and with the liberation of Palestine, the claims of the Jews with their whole services over the Holy Land would be incalculably strengthened. In this study, based on Jabotinsky's letter, which is obtained from British archive records, to the British government for the establishment of the Jewish Legion it is tried to be explained the process of the Zionists' involvement in the war.

Keywords: Jewish Legion, Britain, Palestine, First World War, Vladimir Jabotinsky.

\section{Giriş}

19. yüzyılda, Avrupa'da daha önce başlayan bir eğilimin ardından, dünyanın dört bir yanındaki insanlar kendilerini ulus olarak tanımlamaya ve başta kendi devletlerinde (kendi kaderini tayin ve egemenlik) kendi kendini yönetme hakkı olmak üzere ulusal haklar talep etmeye başladı. Bu tarihi dönemde özellikle Avrupa'da yaşayan Yahudiler ulusal bir bilinç geliştirmeye başladılar ve bu amaca ulaşmak için harekete geçti. Yahudiler dünyaya (diaspora) yayıldıkları için, ulusal hareketleri olan Siyonizm, Yahudilerin göç ve yerleşim sürecinde bir araya gelebilecekleri bir yerin belirlenmesini gerektiriyordu. Siyonistler için Filistin mantıklı ve en uygun yer gibi görünüyordu. Bu düşünce doğrultusunda 1882'de, Osmanlı toprağı olan Filistin'e ilk Avrupa Yahudi göçü dalgası başladı. ${ }^{1}$ 20. yüzyılın başlarına kadar Filistin'de yaşayan Yahudilerin çoğu, dini öneme sahip dört şehirde yoğunlaşmışt1; Kudüs, El Halil, Safed ve Tiberya bu bölgelerin en önemlileriydi. ${ }^{2}$

Siyonizm temel amac1, tüm Yahudilerin anti-semitizme karşı tek çözümün, olabildiğince çok Yahudi'nin Filistin/İsrail'de toplanması ve orada bir devlet kurulması olduğu yönündeydi. Theodor Herzl tarafından 1897'de kurulan Dünya Siyonist Örgütü, Siyonizm'in amacının 'kamu hukukuyla güvence altına alınan Yahudi halkı için ulusal bir yuva" kurmak olduğunu ilan etti. ${ }^{3}$ Siyonizm, 19. yüzyılın sonlarında ve 20. yüzyılın başlarında Rusya İmparatorluğu'nda yaşanan Yahudi karşıtı ayaklanmaların (pogrom olarak da bilinir) bir sonucu olarak Yahudiler arasında taraftar buldu ve Batı'dan destek kazandı. Osmanlı Devleti zayıflıyordu ve Avrupalı güçler, Filistin de dahil olmak üzere Doğu Akdeniz'deki bölgelerde hakimiyetlerini sağlamlaştırıyordu. Birinci Dünya Savaşı'nın patlak vermesi Siyonist hareketin gerçekleşmesi için politik bir ortam yarattı. Siyonistler, bu süreçte İngiltere'nin yanında yer almalarının Yahudi amaçlarına daha çok hizmet edeceği düşüncesindeydi. İngiltere'yi siyasi olarak desteklemek yetmeyebilirdi. Somut olarak savaşa dahil olmak savaş sonrası alınacak kararlara müdahil olmak önemliydi. Bunun olabilmesi de Yahudi askeri birliklerinin savaşa katılması düşünülmüştür. Bu düşünceyi ortaya atan ve Yahudi lejyonlarının kurulmasını sağlayan önemli kişilerden birisi de Zeev (Vladimir) Jabotinsky’dir.

1 Nuh Arslantaş, “İslami Dönemde (638-1099) Filistin’e Yahudi Göçü (Aliya)”. Belleten, Cilt: LXXV, Sayı: 274, (2011), 641.

2 Margalit Shilo, "The First World War: An Arena For The Empowerment of Women in The Jewish Community in Palestine". Journal of Modern Jewish Studies, 7/1, (2008), 2.

3 Ali Akyıldız-Zekeriya Kurşun, Osmanlı Arap Coğrafyası ve Batı Emperyalizmi. (İstanbul: Türkiye İş Bankası Kültür Yayınları, 2018), 41. 
Vladimir Jabotinsky (1880-1840), Ukrayna'nın Odessa kentinde 1880 y1lında dünyaya geldi. ${ }^{4}$ Jabotinsky, Roma'da hukuk okumaya gitmeden önce memleketi Odessa' da Rus eğitimi aldı. Gazeteci olması ve dil öğrenme konusunda yeteneği onun güçlü bir propagandacı ve konuşmacı olmasında etkili oldu. Siyonizm'e olan ilgisi, 1903 Rus katliamlarıyla başladı ve Siyonist Kongreleri ve toplantılarına düzenli olarak katıldı. Jabotinsky'nin bağımsız bir Yahudi devleti kurma taahhüdü mutlaktı ve Birinci Dünya Savaşı'nda enerjisini Yahudi Lejyonunu kurmaya harcadı. Görüşleri, Chaim Weizmann da dahil olmak üzere diğer Siyonist liderler tarafindan paylaşılmadı, ancak Yahudi Lejyonu projesinde başarılı oldu ve 38. Tabur'da görevlendirildi. Savaştan sonra Jabotinsky, Siyonist komisyonda siyasi görevli olarak kısa bir süre geçirdi, ancak İngiliz yetkililerin Balfour Deklarasyonu'nun vaatlerini yerine getirmediğini düşündüğü için istifa etti. Haganah'in lideri olarak 1920'deki Arap-Yahudi isyanlarına katıldı, tutuklandı ve ardından serbest bırakıldı. Daha sonra Siyonist yönetime hizmet etti ve Siyonist gençlik hareketi Betar'ın kurucusu oldu ve manda dönemi boyunca var olan sosyalist Siyonist gruplara karşı revizyonist harekete liderlik etti. 1940 yılında, bölgedeki yönetim tarafından Filistin'den uzaklaştırıldıktan sonra Jabotinsky, New York'taki öldü. ${ }^{5}$

\section{1. İngiltere Hizmetindeki İlk Yahudi Lejyonu: Yahudi Katır Birliği}

İngiltere'nin de desteğiyle Siyonistler Birinci Dünya Savaşı'nın başladığı 1914 yılında Filistin'de, 418.000 dönüm toprağa ve 47 yerleşim merkezine sahip olmuştu. Siyonistler, bulundukları bu toprakların korunması için Yahudi göçmenlerden oluşan "Gece Zaptiyeleri" (Haşomer) adını verdikleri milisler kurarak Arap saldırılarına karşı koymaktaydılar. Bu milislerin Yahudi yerleşim bölgelerini koruyan sınırlı bir güce sahip yasal olmayan bir teşkilat olduğu belirtilmektedir. Siyonistlerden oluşan bir lejyon fikri ilk olarak 1914 Kasım'ında İstanbul Üniversitesi mezunu Yitzhak Ben-Zvi tarafından Kudüs'teki Osmanlı kumandanına teklif edilmişse de, bu düşünce kabul görmemiş̦tir. ${ }^{6}$

Birinci Dünya Savaşı'nda hizmete girecek bir Yahudi Lejyonu kavramı, bir süredir birçok Siyonist'in kafasında yer almıştı. Yahudi ulusal rönesansının bir unsuru olarak askeri faaliyetlerin en önde gelen savunucusu olan Siyonist Vladimir Jabotinsky, Müttefiklere Filistin'i Türk yönetiminden kurtarmada yardımcı olacak Yahudi askeri gücü fikrini dile getirdi. Yahudi lejyonlarının fikir babası Vladimir Jabotinsky, savaşın patlak vermesiyle, Russkie Vedomosti gazetesi adına Batı Cephesine gönderildi. Osmanlı Devleti'nin savaşa girmesi Jabotinsky'e harekete geçme firsatı verdi ve "Kaderimiz Eretz İsrail'de Türk yönetiminden kurtulmaya bağlı ve bu savaşa bir Yahudi askeri birliği olarak katılmalıyız.” dedi. Madrid’de Siyonist Örgütün siyasi kolu lideri Max Nordau ile bir araya geldi ve Eretz İsrail'i Türk egemenliğinden kurtarmak için müttefiklerin yanında savaşacak bir Yahudi gücü kurmalarının gerektiğini ileri sürdü. Nordau, Jabotinsky'nin "hem hayali hem de istenmeyen planını kesinlikle reddediyorum" diyerek bu teklifi reddetti. Bu dönemde Yahudiler, Filistin'den Mısır'a toplu bir şekilde göç etmeye başlamıştı.

4 http://en.jabotinsky.org/zeev-jabotinsky/life-story/childhood-and-youth/

5 Martin Watts, The Jewish Legion and The First World War, (New York: Palgrave Macmillan, 2004), 15.

6 Mim. Kemal Öke, "Çanakkale Savaşlarında Siyonist Alayı'nın Faaliyeti”. İstanbul Üniversitesi İktisat Fakültesi Mecmuasl, C. 43, Prof. Dr. S. F. Ülgener’e Armağan, İstanbul, (1987), 404.

7 http://en.jabotinsky.org/zeev-jabotinsky/life-story/the-legion-and-the-hagana-defense/ 
3 Mart 1915'te, sekiz kişilik bir Yahudi komitesi toplandı. Bu toplantıda Siyonist liderlerden Vladimir Jabotinsky ve Joseph Trumpeldor, bir Yahudi lejyonu kurulması için bir plan sundular. Jabotinsky'nin, bir Rus kahramanı olan Joseph Trumpeldor ile tanışması bir Yahudi birliğinin kurulmasını kolaylaştırdı. Yüzbaşı Trumpeldor, 1904-1905 Rus-Japon Savaşında bir kolunu Port Arthur'da kaybetmiş ve Japonlara esir düşmüştü. Rusya’ya döndügüünde bizzat Çar II. Nikolay’ın elinden kuşatma sırasındaki cesaretinden ötürü St. George Nişanı madalyasını alan bir Yahudi'ydi. ${ }^{8} \mathrm{Bu}$ ikili, daha sonra İskenderiye'de Mafruza Kampı'nda 200 kişilik bir grupla, bir toplantı gerçekleştirdi. Toplantı sonunda oy birliği ile Britanya İmparatorluğu'nun safında, Yahudi gönüllülerden oluşan bir birlik kurarak savaşa katılmak için İngiliz askeri yetkililerine başvurma kararı aldılar. Ancak bir süre sonra Vladimir Jabotinsky ve Joseph Trumpeldor arasında fikir ayrılığı ortaya çıktı. Bu iki Siyonist önder arasında fikir ayrılığının çıkmasının nedeni, oluşturulacak olan Yahudi askeri gücünün hangi cephede Osmanlı Devleti'ne karşı savaşacak olmasıydı. Jabotinsky, özellikle, Filistin Cephesi'nde aktif görev alacak bir birliğin kurulmasını düşünürken, Mısır'daki İngiliz Komutanlığı'nın kararı çok farklıydı. Mısır'daki İngiliz Komutanı General John Maxwell, ordu yasası uyarınca yabancı uyrukluları savaşan birlikler olarak kabul edilemeyeceğini, ancak onları gönüllü bir taşıma Katır Birliği haline getirebileceğini söyledi. Mısır'daki İngiliz kuvvetlerinin komutanı General Maxwell, böyle bir birliğin, yeni açılacak olan Gelibolu Cephesi'nde kullanılmasını uygun görmüştü. Trumpeldor da bu konuda fikrini şöyle dile getirecekti: "Saldırıya kuzey ya da güney hangi cepheden başlanacağı teknik bir sorundur, her cephe Sion'a götürecektir." General Maxwell tarafından resmi olarak tarihe "Zion Mule Corps" yani Siyon Katır Birliği olarak geçecek birliğin başına, Yarbay John Henry Patterson atand1. ${ }^{9}$ Patterson, Güney İrlandalı Protestan kökenliydi. Yahudi tarihi hakkında bilgi sahibi ve Siyonist davaya sempati duyuyordu. 1915 İlkbaharının başlarında Yahudi askerler, İskenderiye Büyük Hahamı Raphael della Pergola tarafından müttefiklerin davasına bağlılık yemini ettiler ve 2 Nisan'da eğitim için kampta alındılar. Kısa bir eğitimden sonra Katır Birliği, 17 Nisan 1915'te iki gemi ile Gelibolu'ya doğru yola çıktı. ${ }^{10}$ Askeri birlikte yaklaşı 500 asker bulunurken, subaylar ve kıdemli astsubayların binmesi için 20 at ve nakliye işi için de 750 katır vardı. Patterson'un emrinde beş İngiliz ve sekiz Yahudi subayı vard1. ${ }^{11}$ Patterson'a yardımcı olarak da binbaşı rütbesine terfi ettirilen Joseph Trumpeldor getirildi. Trumpeldor, Rus-Japon savaşı sonrasında Filistin'e yerleşerek çiftçilik yapmış, Birinci Dünya Savaşı'nın başında da İskenderiye’ye yerleşmişti. ${ }^{12}$

İngiliz tarihinde ilk kez Britanyalı veya sömürgeci olmayanların İngiliz kuvvetlerine bir birim olarak katılması kabul edilmişti. Siyonistlerin emelleri ise çok daha farklıydı. Siyonistler, İngilizleri kullanarak Filistin'e yerleşmek için Gelibolu'ya gidiyorlardı. Magen David'i (Davud'un Yıldızı) sembol olarak kabul ettiler ve askeri talimler İbranice yapıldı. Bu askeri birlik savaş cephesinin tüm tehlikelerine maruz kalmasına rağmen, gerçek bir cephe savaş içerisinde yer almamıştı ki zaten İngilizler de böyle bir beklenti içinde değildi. Bu birliğin özel görevi, siperlerdeki birliklere su ve diğer gerekli malzemeleri sağlamaktı. Gelibolu yarımadasının güney kesimindeki Alçı Tepe'nin eteklerinde birkaç ay boyunca dönemin en şiddetli savaşlarında kendilerine verilen

8 J. H. Patterson. With the Zionists in Gallipoli. (New York: George H. Doran Company, 1916), 50.

9 Martin Watts, The Jewish Legion and the First World War. (New York: Palgrave Macmillan, 2004), 20.

10 Patterson, With the Zionists in Gallipoli. 51.

11 Patterson. With the Zionists in Gallipoli. 61.

12 Mim. Kemal Öke, "Çanakkale Savaşlarında Siyonist Alayı’nın Faaliyeti”. 410. 
görevleri sadakatle yerine getirdiler. ${ }^{13}$ Siyon Katır Birliği, 29. Tümen'in emrindeki görevini, 9 Ocak 1916'da Gelibolu'nun, Müttefiklerce boşaltılıp tahliye edilmesine kadar, 8 er ve 47 katırı Çanakkale topraklarında bırakarak, İngiliz hükümetinin övgü ve minnettarlığı arasında Haziran 1916'da feshedildiği Mısır'a döndü. ${ }^{14}$

\section{Yahudi Lejyonunun Kurulması İçin İngiltere'den Yardım İsteği}

Birinci Dünya Savaşı'ndaki gelişmeler Siyonist hareketin diplomatik manevraları için altın bir firsat sunmaktaydı. Özellikle 1917'de İngiliz hükümetinin, Filistin'de Yahudi halkı için ulusal bir yuva kurulmasını taahhüt eden Balfour Deklarasyonu'yla büyük bir dünya gücünün siyasi desteğini sağlayan Yahudiler, siyasi Siyonizm için önemli bir başarı elde etti. ${ }^{15}$ Mısır ve Hindistan'1 birbirine bağlayan önemli topraklar üzerinde İngiliz hegemonyasını sürdürecek savaş sonrası jeopolitik ve stratejik bir hedef olarak Filistin'de bir işbirlikçi Siyonist devlet, İngiliz çıkarlarına da hizmet edebilirdi.

Yarbay John Henry Patterson komutasındaki Zion Katır Birliği, Gelibolu seferi sırasında 1915’te kendini tanıtmıştı. Ancak bu Katır Birliği cephe gerisinde kullanılmıştı. Yahudilerin savaş meydanında daha etkin rol alması için Jabotinsky'ye göre, gerçek manada cephede savaşan bir Yahudi askeri birliğinin kurulması önemliydi. Jabotinsky, İtalya ve Fransa'ya giderek birliği kurma mücadelesine destek için tanıdığı devlet adamlarıyla görüştü. Bu çabaları sonuç vermeyince İngiltere'ye gitti ve İngiliz hükümetini Yahudi lejyonu konusunda ikna etmeye çalışt. ${ }^{16}$

Jabotinsky, İngiltere Başbakanına (David Lloyd George) 24 Ocak 1917 tarihinde bir mektup yazdı. Bu mektupta Filistin ve Mısır'da savaşmak için bir Yahudi Alayının kurulması teklifinde bulundu. Bu Yahudi Alayı planının çeşitli siyasi meselelerle bağlantılı olacağından, talebin doğrudan başbakana sunulmasının tavsiye edildiği ve konunun değerlendirilerek savaş kabinesi ve ilgili diğer yetkililerin görüşüne sunulması bizzat başbakandan rica edilir.

Jabotinsky mektubunda Gelibolu'da İngiliz Ordusu ile hizmet veren Sion Katır Birliği'nin üstlendiği rolü ve Trumpeldor'un faaliyetlerini belirten belgelerin kopyalarını da mektubuna ekler. Mektupta, Katır Birliğinin kurulmasından sonra, daha büyük bir Yahudi lejyonunun oluşturulması için Londra ve Kahire'de yetkililerle görüşmeler yapıldığı, Eylül ve Ekim aylarında, Londra'nın doğusunda günlük bir gazeteye ilan verilerek ve halka açık toplantılar yapılarak asker toplama kampanyası düzenlendiği ifade edilir. Bu eylemler için içişleri bakanının kişisel onayını aldıklarını ancak resmi desteğin reddedildiği, yetkililerin umursamazlığı yüzünden propaganda çalışmalarının yarıda kaldığı mektupta yer almaktadır.

İngiltere'nin Filistin saldırısını başlatması Siyonistleri de heyecanlandırmıştı. Jabotinsky, mektubunda Yahudi lejyonunun kurulması için başbakana, "bu isteği size iletirken, sadece Başbakan'a değil, aynı zamanda küçük bir ulusun duygularını bilen bir adama da hitap ettiğimizi söylemek isteriz" diyecektir. Mektupta hesap günü Yahudilerin unutulacağından korktuklarını, taleplerini dile getirme şansı, ülkeleri için savaşmak istediklerini, isimsiz ve dağınık değil kendi

13 Max Raisin, History of The Jews in Modern Times, (New York: Hebrew Publıshıng Company, 1919), 430.

14 https://www.jewishvirtuallibrary.org/the-zion-muleteers-of-gallipoli

15 Tariq Dana-Ali Jarbawi, "A Century of Settler Colonialism in Palestine: Zionism's Entangled Project”. The Brown Journal of World Affairs, Fall/Winter, Volume XXIV, Issue I, (2017), 6.

$16 \mathrm{http} / /$ en.jabotinsky.org/zeev-jabotinsky/life-story/the-legion-and-the-hagana-defense/ 
Alaylarıyla cephede yer almaları gerektiğini ifade eder. ${ }^{17}$

Başbakana gönderilen mektupta, Yahudi lejyonun oluşturulma planıla ilgili bir taslak sunulur. Bu taslak metinde İngiltere hükümetinin, Filistin ve Mısır' da savaş hizmeti için bir Yahudi Alayı oluşturması, oluşturulacak bu Yahudi Alayının Birleşik Krallıkta, Mısır'da veya diğer Dominyonlarda gönüllü asker toplama veya diğer yöntemlerle askere alınacak Rus Yahudilerinin sayısı, Fransa'da ile tarafsız ülkelerde gönüllü olarak askere alınacak Rus Yahudilerinin sayısının belirlenmesi ve bu birime hizmet etmek için gönüllü İngiliz vatandaşlarından Alayın çekirdeğini derhal oluşturması istenir. Misır'da kayıtlı 150 Rus Yahudisinden çoğunun Londra'da 20. Taburda eğitim gördüğü belirtilmektedir. Mısır'a gitmek için kaydolan ikinci Rus Yahudi grubundan, birkaç hafta içerisinde bir araya gelmesi beklenen toplam 280 kişi ve 25 Ekim 1916'dan önce Londra bölgesindeki gönüllü Rus Yahudilerinin oluşturduğu toplamda yaklaşık 200 kişinin bulunduğu belirtilir.

Jabotinsky, İngiliz hükümetinden oluşturulacak Yahudi lejyon birliklerinde görev alacak İngiliz komutanların seçiminde, rütbe, din veya ırk ayrımcılığı yapmayan komutanların atanmasını ister. İngilizler tarafından eğitilen askeri birliklerde (The Officers' Training Corps) eğitim almış İngiliz Yahudilerinin bu birliklerde gönüllü olarak görev almasına firsat verilmesi istenir. Hükümetteki yetkili makamların rızası ile belirlenecek yerlerde askere alma kampanyasına izin verilmesi, çalışmaların yürütülmesi için kolaylık sağlanması ve kampanya için talep edilmesi halinde personel ve fon sağlanması da istenir. ${ }^{18}$ Belirtilen isteklerin dile getirilmesinde imzası olanların Mısır'daki Yahudi mülteciler arasındaki hareketin öcüleri olan ve Sion Katır Birliğinin oluşumunu sağlayan Pattorson ve Trumpelder gibi kişilerin Gelibolu cephesinde görev aldığı ve İngiliz askeri yetkililerinin takdirini kazandığı mektupta dile getirilir.

Mektupta Siyonistlerin başlangıçtaki planlarının Filistin cephesi için savaşan bir Yahudi lejyonu oluşturmak olduğu, ancak dönemin askeri gereksinimleri nedeniyle (Mart 1915), küçük bir nakliye biriminin oluşturulduğu belirtilir. Yine de en başından beri İngiltere ve Mısır'daki yetkililerden savaş hizmeti için daha büyük bir Yahudi lejyonu fikrini savundukları ve en son EylülEkim aylarında, İçişleri Bakanı'nın onayı ile Londra'nın doğu kesiminde Hükümete herhangi bir masraf teşkil etmeden sağlanan kaynaklarla asker alımının organize edildiği belirtilir. İngilizlerin Filistin'de ilerlemesi, Ülkede askerlik çağında 30.000'den fazla Rus Yahudi'sinin bulunması ve askeri kullanım sorununun hala çözümsüz olması gerçeği, Doğu Avrupa'daki Yahudilerin durumu, bu çalışmaların devam ettirilmesinin gerekliliğinin önemi vurgulanır. Hemen bir Yahudi birliğinin oluşturulması, askerlik çağındaki yabancıların sorunun çözülmesi, istenilen bir cephede görev verilmesi işleri planın hayata geçmesini hızlandıracaktı. Jabotinsky, İngiliz Hükümetinin bu savaşla bağlantılı olarak Yahudi sorununun, tamamen farkında olduğuna inandıkları vurgusunu belirtikten sonra, "Bu savaş sadece silahlı kuvvetlerin değil, aynı zamanda siyasi ilkelerin de çatışmasıdır. Açıktır ki, tarafsı ülkeler ve özellikle on binlerce Yahudi'nin hayatın her dalında önemli ve onurlu roller oynadığı Amerika, bazı ülkelerdeki Yahudi halkının anormal durumunu görmezden gelemez ve Batılı güçlerin bu sorundaki sessizliği yanlış yorumlanacaktır" ifadesini belirtir. Bu nedenle, Yahudi isteklerinin karşılanmasında tek yol, Yahudi halkının Siyonist idealini resmi olarak tanımak ve Yahudi gençlerinin müttefiklerin yanında Filistin'in özgürlüğü için savaşmaya çağrılması olarak

17 The National Archives' reference CAB 24/9/55-239.

18 CAB 24/9/55-240 
ifade edilir. ${ }^{19}$

İngiltere'de bu dönemde askerlik çağında otuz bin Rus Yahudi'si bulunmaktaydı. İngiliz hükümetinin bu durumdan faydalanabileceği belirtilir. Eylül ve Ekim 1916'da Doğu Yakası Yahudileri arasında askere alma kampanyalarının başarısız olmasındaki temel sebebin, Yahudi Lejyonu Planının herhangi bir resmi onayının olmamasından kaynaklandığı belirtilir. Jabotinsky, Filistin için bir Yahudi birliğine katılma çağrısının yetkililer tarafından onaylanması halinde sonucun farklı olacağı konusunda ısrar eder. Askere alma kampanyasının ilk adımı olarak, elde var olan çekirdek kadrodan hemen bir birliğin oluşturulması önerilir ve bunun gönüllü kayıt için güçlü bir propaganda aracı oluşturacağ 1 söylenir. Gönüllü birliklerin yeterli olacağ1 söylense de aksi durumda hükümetin zorunlu yöntemleri kullanmaya karar vermesiyle, Yahudi Alayı programının kendisini daha güçlü hissedebilirdi. Yine de Filistin'de Yahudi geleceği için savaşacak bir Yahudi birliğine zorunlu askerlik yaptırılması, ülkede sürtüşme ve yurtdışında eleştirilere neden olacağ düşünülmektedir. Filistin için bir Yahudi Alayı'nın kurulmasının, çoğu yüksek eğitimli olan Fransa'dan ve bazı tarafsız ülkelerden (özellikle İsviçre ve İskandinavya) birçok Rus Yahudisini hemen çekeceğinden umutla bahsedilir. Bu Avrupalı acemi erlerin politik değeri sadece onların sayılarıyla ölçülmemeli, bunların her biri, İtilaf devletlerine tamamen kendiliğinden bir güvenin tezahürü anlamına geleceği vurgulanır. Bu olası askere alımda Amerika ve Rusya üzerinde kesinlikle ısrar edilmesinden kaçınılması gerektiği, belki daha sonraki bir aşamada sorunun bu yanının da dikkate alınabileceği belirtilir. Amerikan Yahudileri için bir askere alma kampanyası, tarafsızlı̆̆a aykırı olmayan bir biçimde ve profesyonel olarak düzenlenebileceği, Rusya'da on binlerce eğitimli Yahudi gencin bulunduğu, seferber edilmemiş büyük bir genç adam rezervine sahip olduğu, eğer resmi olarak talep edilmesi halinde Rus Hükümeti'nin gönüllülerin gelmesine izin vermeye isteksiz olmayacağ belirtilir. $^{20}$

Jabotinsky mektubuna görüşlerini desteklemesi için daha önce yaptıkları çalışmaların örneklerini eklemiştir. Belgede, 1915 yılı başlarında Yüzbaşı J. Trumpeldor'un, Sion Katır Birliği’nde Albay Patterson'a yardımcı olarak atandığı ve 27/4/15 tarihinden tahliye tarihine kadar da Gelibolu'da görev yaptığı belirtilir. ${ }^{21}$

Başka bir belgede Çanakkale Savaşı'nda Akdeniz Seferi Kuvvetlerine komuta eden Ian Hamilton'ın Jabotinsky'ye gönderdiği cevap mektubunu ekler. Bu mektupta Hamilton, "Mektubunuzu tüm sevgimle karşıladım. En başından beri Sion Katır Birliği ile çok ilgilendim. Askerlerin görünüşünü beğendim ve birliği ayaklarl üzerinde tutmak için her zaman özel olarak ilgilendim. Ayrılmadan hemen önce, erkeklerin yarısının bir aylık iyi bir izinle (tam maaşla) İskenderiye'ye geri gönderilmesini ayarladım ve bu sayede daha fazla asker alınacağını ummuştum. Askerler son derece iyi iş çıkardılar, görevlerini ağır mermi ve tüfek ateşi altında sakin bir şekilde yaptılar. Umarım çabalarınızda başarılı olursunuz". ${ }^{22}$ sözleriyle Yahudi lejyonuna desteğini belirtir. Asker toplama için kullanılan Siyonist gazete "Jewish Tribune" nin 1'den 23'e kadar olan sayılarının Yidişçe (Yiddish) basıldığı ve her sayısında İngilizce bir makaleye yer verildiği bilgisi

19 CAB 24/9/55-241.

20 CAB 24/9/55-243.

21 CAB 24/9/55-243.

22 CAB 24/9/55-244. 
mektuba eklenmiştir. ${ }^{23}$

Jabotinsky’nin çabaları İngiltere çevrelerinde etkili olmaya başlamıştı. Jabotinsky'nin Orta Doğu'da yapılacak İngiliz askerî harekâtı için özellikle gönüllü olmak üzere 1srarı ve desteğine yanıt veren İngiltere, Savaş Kabinesinin 23 Ağustos 1917'de bir Yahudi Lejyonu kurulması kararını onayladı. Vladimir Jabotinsky tarafından müttefiklerin savaşına yardımcı olmak için Britanya, Kanada ve Amerika'daki Yahudiler ve yerel Yahudilerden oluşturuldu. ${ }^{24}$ İngiltere ordusunun bir parçası olarak Lejyon, 38. 39. 40. ve 42. olmak üzere dört taburdan oluşuyordu. İngiliz gönüllülerden oluşan 38. Tabur, Yarbay Patterson'un komutası altındaydı ve 39. Tabur Kuzey Amerikalı gönüllüler, bir İngiliz Yahudisi olan Yarbay Margolin tarafından komuta ediliyordu. 40. ve 42. Taburlar Filistinli gönüllülerdendi. ${ }^{25}$ Şubat 1918 'de, Lejyon askerleri Londra' da topluca yürüdükten sonra Filistin'deki cepheye doğru yola çıktılar. Toplamda 10.000 kişis Lejyon'a kaydolsa da bu sayının yalnızca yarısı Filistin'e ulaştı. Bu birlikler İngiliz General Edmund Henry Hynman Allenby'nin emrinde Filistin taarruzunda kullanıldı. ${ }^{26}$

Yeni Yahudi askerleri kapsayacak şekilde kurulan lejyonlar, Kraliyet Alayı'nın (Royal Fusiliers) bir parçasıydı. İlk lejyonu İngiltere'ye Yahudi göçmeni olarak gelenlerden oluşturulan 38. Kraliyet Fusiliers Lejyonu idi. 31 Ekim 1917'de General Edmond Allenby komutasinda başlatılan Filistin harekatının ana savaşlarına katılabilmek için kurulması kararlaştırılan birliğin kuruluşu çok geç oldu. Bununla birlikte, Kraliyet Alayının 38. ve 39. Lejyonları (Birleşik Devletler ve Kanada'da işe alınan gönüllülerin büyük bir bölümünü içeriyordu) 1918 baharında Allenby’nin Ürdün Vadisi üzerindeki savaşlarında yer aldılar. Bölgedeki Araplara, Yahudi isteklerinden daha stratejik önem veren Allenby, Yahudi Lejyonlarına karşı çok sıcak bakmamıştır. Yahudilerin işçi lejyonları olmaları gerektiğini düşüncesiyle onları Batı Hint lejyonları ile birleştirmek istemiştir. 40. Lejyonun Filistin'in Yahudi sakinlerinden alınmasına izin verirken Allenby, bu lejyonları Yahudi tugayına dönüştürmek veya onları Filistin işgalinde büyük bir güç olarak kullanmak için herhangi bir girişimden kaygı duymaktaydı. Lejyonerlere Ürdün Nehri üzerindeki köprüleri koruma ve Türk savaş esirlerini denetleme gibi görevler verildi. Ateşkesin ardından Lejyonlar, Allenby'nin karargâhı tarafından daha da ötekileştirildi. Statüleri konusundaki belirsizliğin devam etmesi üzerine Lejyonerler zaman zaman tepkilerini dile getirmişlerdi. 1919'un sonunda, küçülen lejyonlar, sembolleri Menora'nın olan "Birinci Yahudi Taburu” unvanının verilmesiyle bir süre rahatlamışlardı. Ancak Londra Savaş Bürosu'nun sembolik hareketi lejyonları Filistin'de Araplar ve Yahudiler arasındaki çatışmalara müdahale etmelerini engelleyemedi. Nisan 1920'de, Birinci Yahudi Taburu'na katılan Jabotinsky, Arapların Kudüs’teki Yahudilerle çatışmasında şiddet uygulaması 19 kişi ile birlikte tutuklanmasına ve bir İngiliz askeri mahkemesi tarafından 15 yıl hapis cezasına çarptırılmasına neden oldu. Mayıs 1921'de, Yafa'daki çatışmalar sırasında Tabur kampa kapatıldı ve dağıldı. Bu Yahudi Lejyonları Jabotinsky'nin devasa bir Yahudi gücü vizyonuna uymamasına ve Birinci Dünya Savaşı'nın muazzam savaşlarındaki sınırlı rolüne rağmen hem İsrail'de hem de Kuzey Amerika'da Yahudi ulusal özlemlerinin temeli olarak anılmaktadır. Bu

23 CAB 24/9/55-245.

24 Gudrun Kramer, A History of Palestine, From The Ottoman Conquest To The Founding of The State of Israel. (New Jersey: Princeton University Press, 2008), 153.

25 Zachariah Kay, “A Note on Canada and the Formation of the Jewish Legion”. Jewish Social Studies, Vol. 29, No. 3 (Jul., 1967), 172.

26 Öke, “Çanakkale Savaşlarında Siyonist Alayı'nın Faaliyeti”. 413. 
orduyu Filistin'de karşılayan Yahudiler, "Çanakkale'deki Siyon Katır Alayı oğlumuzdu; bu Siyon Lejyonu ise torunumuzdur" diyebilmişlerdi. ${ }^{27}$ Daha sonra lejyon gazileri, Haganah örgütünün kurulduğu üs haline geldi. ${ }^{28}$

\section{Sonuç}

Jabotinsky'e göre yüzyıllarca gettolarda pasif bir yaşama itilen Yahudilerin bir millet olmaya hak kazanabilmeleri için, askeri bir disiplin almaları ve cephelerde ön saflarda çarpışma sınavını geçmeleri gerekliydi. Yahudiler ancak bu ateşten gömleği giydikleri takdirde kendilerini dünya devletlerine kanttlayacaklar ve kendilerine ait bir ülkeye sahip olabileceklerdi. Bu mücadeleyi Yahudilerin tek başına verebileceklerini mümkün görmeyen Jabotinsky, amaca ulaşmak için İngiltere'nin desteğinin alınması zorunluluğu karşısında İngiliz başbakanına taleplerini dile getiren mektubunu göndermiştir. Yahudi taleplerinin İngiltere'ye gönderilmesinde şüphesiz İngiltere'nin yönetim çevrelerinin ve İngiliz vatandaşlarının çoğunun, kendilerini her zaman Yahudi ırkının samimi dostları olarak göstermeleri etkili olmuştur. ${ }^{29}$ Jabotinski'ye göre Balfour Bildirisi ilanını Çanakkale'deki Siyon Katır Alayına borçludur. Müttefiklerin desteğinin sağlanmasında Yahudi lejyonlarının önemli bir araç olabileceğinin önemini anlayan Vladimir Jabotinsky, Joseph Trumpeldor ve Pinhas Rutenbeg dahil Siyonist aktivistler savaşın cephesinde yer almak için her yolu denemiş ve bunda da bir nevi başarı sağlamışlardı. Yahudi Lejyonu genellikle Yahudilerin toprak üzerindeki iddiasını güçlendirmek için Filistin'in Türklerden alınması yönündeki Siyonist çabalarının zaferi olarak görüldü. Geleneksel olarak Yahudi lejyonu olarak bilinen Birinci Dünya Savaşı sırasında Filistin'deki İngiliz Seferi Kuvvetleri ile bağlantılı Yahudi taburlarının tarihi, Yahudi devletinin yeniden canlanmasını çevreleyen kahramanlık mitinin de bir parçası haline geldi. Filistin'in Siyonist kolonizasyonu Osmanlı yönetiminin son döneminde başlasa da, İngiliz Mandası altında gelişmiştir.

\section{Kaynakça}

The National Archives' reference CAB 24/9/55-239.

The National Archives' reference CAB 24/9/55-240.

The National Archives' reference CAB 24/9/55-241.

The National Archives' reference CAB 24/9/55-243.

The National Archives' reference CAB 24/9/55-244.

The National Archives' reference CAB 24/9/55-245.

Akyıldız, Ali-Kurşun, Zekeriya. Osmanlı Arap Coğrafyası ve Batı Emperyalizmi. İstanbul: Türkiye İş Bankası Kültür Yayınları, 2018.

Arslantaş, Nuh. “İslami Dönemde (638-1099) Filistin’e Yahudi göçü (Aliya)". Belleten, Cilt: LXXV, Say1: 274, 2011, 641-689.

27 Shlomit Keren-Michael Keren. "The Jewish Legions in The First World War As A Locus of Identity Formation". Journal of Modern Jewish Studies, 6:1, (2007), 71.

28 Vladimir Jabotinsky. The War And the Jew. (New York: The Dial Press, 1942), 26.

29 Max Raisin, History of The Jews in Modern Times. (New York: Hebrew Publıshıng Company, 1919), 431. 
Dana, Tariq-Jarbawi, Ali. “A Century of Settler Colonialism in Palestine: Zionism's Entangled Project”. The Brown Journal of World Affairs, Volume XXIV, Issue I, Fall/Winter 2017, 1-23.

Kay, Zachariah. "A Note on Canada and the Formation of the Jewish Legion". Jewish Social Studies, Vol. 29, No. 3 (Jul., 1967), 171-177.

Keren, Shlomit-Keren, Michael. "The Jewish Legions in The First World War As A Locus of Identity Formation". Journal of Modern Jewish Studies, 6/1, 2007, 69-83.

Kramer, Gudrun. A History of Palestine, From The Ottoman Conquest To The Founding of The State of Israel. New Jersey: Princeton University Press, 2008.

Öke, Mim. Kemal. "Çanakkale Savaşlarında Siyonist Alayı'nın Faaliyeti”. İstanbul Üniversitesi İktisat Fakültesi Mecmuası, C. 43, Prof. Dr. S. F. Ülgener’e Armağan, İstanbul 1987, 403-414.

Patterson, J. H. With the Zionists in Gallipoli, New York: George H. Doran Company, 1916.

Raisin, Max. History of The Jews in Modern Times, New York: Hebrew Publishing Company, 1919.

Shilo, Margalit. "The First World War: An Arena For The Empowerment of Women in The Jewish Community in Palestine”. Journal of Modern Jewish Studies, 7/1, 2008, 1-15.

Vladimir, Jabotinsky. The War And The Jew. New York: The Dial Press, 1942.

Watts, Martin. The Jewish Legion And The First World War, New York: Palgrave Macmillan, 2004.

http://en.jabotinsky.org/zeev-jabotinsky/life-story/the-legion-and-the-hagana-defense/

https://www.jewishvirtuallibrary.org/the-zion-muleteers-of-gallipoli

http://en.jabotinsky.org/zeev-jabotinsky/life-story/childhood-and-youth/ 